\title{
Material and Fracture Surface Examination of T-Joint for High Pressure Hydrogen Piping that Caused Hydrogen Leakage in a High Pressure Hydrogen Facility
}

by

\author{
Shogo Watanabe*, Takashi Matsuo**, \\ Satoko Yoshida*** and Saburo MatsuoKA***
}

This paper deals with the material and fracture surface examination of T-type joint for piping that caused hydrogen leakage in a high pressure hydrogen facility (Service pressure: $99 \mathrm{MPa}$ ). T-type joint is made of precipitation hardening martensitic 17-4PH stainless steel. The design fracture pressure of T-type joint is as high as $1050 \mathrm{MPa}$. Nevertheless, Ttype joint caused hydrogen leakage in $150 \mathrm{MPa}$ hydrogen gas whose pressure was $14 \%$ of the design fracture pressure. Chemical composition analysis, microstructure observation and Vickers hardness measurement proved that 17-4PH of T-type joint was sound. Fracture surface observation showed that semi-elliptical crack surface was covered with quasicleavage and that peel-like defects were formed on taper surface. It was presumed from these points that hydrogenleakage of T-type joint was caused by hydrogen-induced crack growth from peel-like defect in $150 \mathrm{MPa}$ hydrogen gas.

\section{Key words:}

T-type joint, 17-4PH stainless steel, Hydrogen-leakage, Material and fracture surface examination, Quasi-cleavage, Peel-like defect

\section{1 緒言}

燃料電池自動車の開発は 1990 年後半から本格化し1), 2014 年 12 月に $70 \mathrm{MPa}$ 燃料電池自動車 MIRAI, 2015 年 3 月に CLARITY FUEL CELL が発売された。また， $70 \mathrm{MPa}$ 燃料電池自動車に水素ガスを充填する $70 \mathrm{MPa}$ 水素ステー ションが全国の約 100 個所で建設されている. 燃料電池 自動車と水素ステーションの安全性を向上させるために は，使用材料の水素ぜい化を克服することが不可欠であ る. そのためには, 水素ぜい化に関する基礎研究と事例解 析を平行して進めることが重要である。事例解析として は，水素漏洩を起こしたフレキホース ${ }^{2)}$, 圧力センサー3) の破損解析並びに実証プロジェクト終了後の蓄圧器4), 5), されている.

本研究では, 高圧水素実験施設（常用圧力：99 MPa）で 水素漏洩を起こした高圧ガス配管用 $\mathrm{T}$ 型ジョイントの破 損解析の第 1 報として, T 型ジョイントの材質調査と破面 調查を行う。 $\mathrm{T}$ 型ジョイントは析出強化型ステンレス鋼 17-4PH で作製されていた。 $\mathrm{T}$ 型ジョイントの材質調查の 圧縮水素容器 $\mathrm{VH} 3^{6}$ ), プレクーラー7)の健全性評価が報告

精度を高めるため, 17-4PH と同等である JIS-SUS630 の熱 間圧延板（厚さ $20 \mathrm{~mm}$ ）を準備し, 熱間圧延板についても 材質調査を行う。

\section{T型ジョイントの使用履歴}

Table 1 に, 高圧水素実験施設（常用圧力：99 MPa）に 設置されていた $\mathrm{T}$ 型ジョイントの使用履歴を示す. 17$4 \mathrm{PH}$ 製 $\mathrm{T}$ 型ジョイントの設計破壊圧力は $1050 \mathrm{MPa}$ であ る. 高圧水素実験施設の受け入れ検査において, 水による 而圧試験を高圧水素実験施設の常用圧力 $99 \mathrm{MPa}$ より高い $247.5 \mathrm{MPa}$ で行ったのち, 窒素ガスによる気密試験を 165 $\mathrm{MPa}$ で 1 回, $150 \mathrm{MPa}$ で 2 回, 水素ガスによる試運転と 気密試験を $150 \mathrm{MPa}$ で 3 回行った. 3 回目の水素ガスに

Table 1 Usage history of T-joint.

\begin{tabular}{|c|c|c|c|}
\hline & Hydraulic test & $\mathrm{N}_{2}$ gas test & $\mathrm{H}_{2}$ gas test \\
\hline $1^{\text {st }}$ step & $247.5 \mathrm{MPa}$ & $165.0 \mathrm{MPa}$ & - \\
\hline $2^{\text {nd }}$ step & - & - & $150 \mathrm{MPa}$ \\
\hline $3^{\text {rd }}$ step & - & $150 \mathrm{MPa}$ & $150 \mathrm{MPa}$ \\
\hline $4^{\text {th }}$ step & - & $150 \mathrm{MPa}$ & - \\
\hline $5^{\text {th }}$ step & - & - & $150 \mathrm{MPa}$ \\
\hline \multicolumn{4}{|c|}{ Hydrogen leakage } \\
\hline
\end{tabular}

本報を「高圧水素施設で水素漏洩を起こした高圧配管用T型ジョイントの破損解析（第1報）（Failure analysis of T-joint for high pressure hydrogen piping that caused hydrogen leakage in a high pressure hydrogen facility, I)」とする.

$\dagger \quad$ 原稿受理 令和元年 6月 3日 Received June 3,2019 C2020 The Society of Materials Science, Japan

* 正 会員 水素エネルギー製品研究試験センター テ819-1133 系島市富 Hydrogen Energy Test and Research Center, Tomi, Itoshima 819-1133.

** 福岡大学 $\overline{7} 814-0180$ 福岡市城南区七郎 Fukuoka University, Jonan-ku, Fukuoka 814-0180.

****州大学 水素材料先端科学研究センター † 819-0395 福岡市西区元岡 HYDROGENIUS, Kyushu University, Nishi-ku, Fukuoka 819-0395. 
よる試運転・気密試験を行ったとき, 水素が漏洩した. 水 素ガスによる試運転・気密試験で使用した圧力 $150 \mathrm{MPa}$ は $\mathrm{T}$ 型ジョイントの設計破壊圧力 $1050 \mathrm{MPa}$ の $14 \%$ であ る. 水素ガスによる試運転・気密試験については, 約 5 分 で $150 \mathrm{MPa}$ まで昇圧し，一晚 $150 \mathrm{MPa}$ を保持し，翌日に $150 \mathrm{MPa}$ からの圧力低下を調べたのち, 減圧した.

Fig. 1 (b) に水素漏洩した T 型ジョイント (幅 $75.9 \mathrm{~mm}$, 高さ $57.0 \mathrm{~mm}$ ，厚さ $37.7 \mathrm{~mm}$ ) を示す. Fig. 1 (a) に示す ように, $\mathrm{T}$ 型ジョイントのテーパー部分にき裂が目視で観 察できた.

以上の事実より，水による耐圧試験と窒素ガスによる 気密試験で問題が生じなかったことから, T型ジョイント は適正に作製されていたと判断できる。一方，3回目の水 素ガスによる試運転・気密試験でき裂から水素漏洩が起 こったことから， $\mathrm{T}$ 型ジョイントで使用されていた 174PH の水素ぜい化は破損解析の重要な視点の一つである と考えられる.

3 T型ジョイントと熱間圧延板からの試料・試験片の 切り出し

\section{3・1 T型ジョイント}

Fig. 1 (a) に示すように, T 型ジョイントのテーパー部 分にき裂が存在することが目視で確認できた。き裂は反 対側のテーパー部分にも存在した. この点を考慮し, 破面 観察用試料に加え, 化学成分分析用試料, ビッカース硬さ 試験用試料, 組織観察用試料を $\mathrm{T}$ 型ジョイントより切り 出した. まず, Fig. 1（b）の黄色の線で示した 3 個所を切 断し， A， B， C，Dのブロックに分割した. 分割した様子 を Fig. 2 (a) と（b）に示す. Fig. 2 (b) は, Fig. 2 (a) の 切断面の状態を示したものである.ブロック Aにおいて, き裂から十分離れた場所から組織観察（EBSD : Electron Backscatter Diffraction）用試料，ブロック D から化学成分 分析用試料を採取した (Fig. 2(a)).ブロック Cにおいて, 破面出しを容易にするために, き裂先端から $2 \mathrm{~mm}$ 程度の 余裕を残して余分な部分を切り落とした（Fig. 2 (c)) . 切 り落とした部分からビッカース硬さ測定用試料を採取し た.さらに，破面出しを容易にするために，ブロック C の 上部に切り込みを入れた (Fig. 2 (d)). 切り込みを入れた ブロック $\mathrm{C}$ を液体窒素で 10 分程度冷却し, 急速破壊すな わちぜい性破壊しやすい状態にした後, Fig. 2 (d) の下方 向からハンマーで叨いて破面出しした。

\section{$3 \cdot 2$ 熱間圧延板}

後述する化学成分分析結果とビッカース硬さ測定結果 (Table 2 参照) をもとに，T型ジョイントの 17-4PH と対

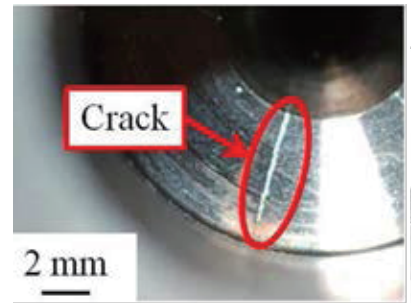

(a) Crack at taper

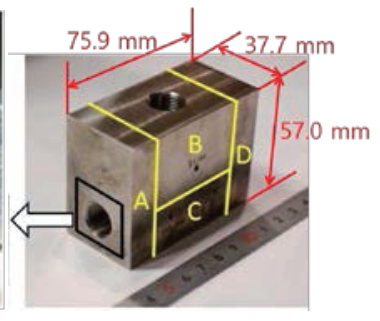

(b) Optical photograph Fig. 1 Hydrogen-leaked T-joint.

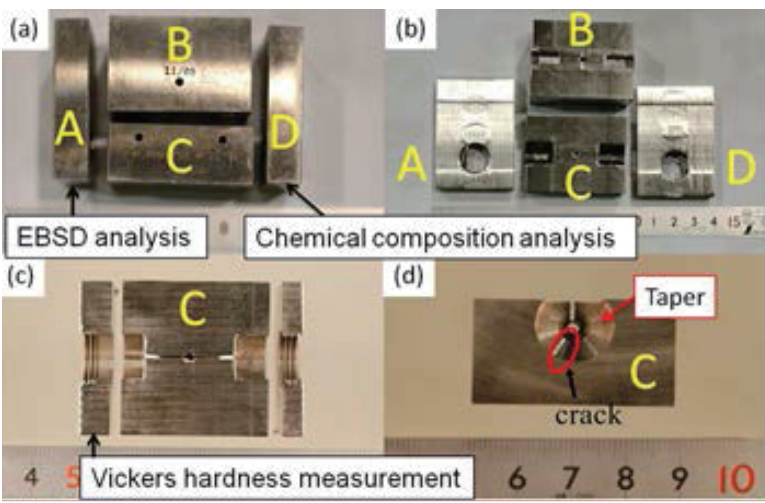

Fig. 2 Samples for chemical composition analysis, EBSD analysis and Vickers hardness measurement.

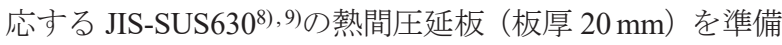
するとともに，準備した熱間圧延板から $70 \mathrm{~mm} \times 70 \mathrm{~mm}$, 厚さ $20 \mathrm{~mm}$ の正方形板を切り出し, 熱処理を行った. 熱 処理として, JS G 4304 で規定される H900 にしたがい, 溶体化処理 $\left(1040^{\circ} \mathrm{C}, 30\right.$ 分, 水冷) した後, 時効処理 $(490$ ${ }^{\circ} \mathrm{C}, 6$ 時間, 空冷) を行った. 時効処理した $70 \mathrm{~mm} \times 70 \mathrm{~mm}$ の板から $7 \mathrm{~mm} \times 7 \mathrm{~mm}$, 厚さ $1 \mathrm{~mm}$ の試料を切り出し, 化 学成分分析, ビッカース硬さ測定, EBSD による結晶方位 解析を行った.

\section{T型ジョイントと熱間圧延板の材質調査 $4 \cdot 1$ 化学成分分析}

$\mathrm{T}$ 型ジョイントは 17-4PH で作製されていると報告を受 けた. そこで，17-4PH に対応する JIS-SUS630 の熱間圧延 板（板厚 $20 \mathrm{~mm}$ ）を準備した. Table 2 に $\mathrm{T}$ 型ジョイント と熱間圧延板の化学成分分析結果を示す. Table 2 には JISSUS630 の規格範囲を JIS 規格 ${ }^{8)}$, 9) から引用して示してあ る. $\mathrm{T}$ 型ジョイントと熱間圧延板の化学成分は一致してお り, JIS-SUS630の規格範囲内であった. この結果から, T 型ジョイントは 17-4PH で作製されたことが確認できた.

Table 2 Chemical composition (mass \%) and hardness of T-joint and hot-rolled plate.

\begin{tabular}{|c|c|c|c|c|c|c|c|c|c|c|c|}
\hline & $\mathrm{C}$ & $\mathrm{Si}$ & $\mathrm{Mn}$ & $\mathrm{P}$ & $\mathrm{S}$ & $\mathrm{Ni}$ & $\mathrm{Cr}$ & $\mathrm{Cu}$ & $\mathrm{Nb}$ & HRC & $H V$ \\
\hline T-joint & 0.047 & 0.002 & 0.66 & 0.023 & 0.002 & 4.2 & 15.05 & 3.3 & 0.22 & - & 448 \\
\hline Hot-rolled plate & 0.04 & 0.32 & 0.77 & 0.25 & 0.011 & 4.73 & 15.46 & 3.27 & 0.4 & - & 440 \\
\hline $\begin{array}{c}\text { SUS630 } \\
\text { (JIS G 4303) }\end{array}$ & $<0.07$ & $<1.00$ & $<1.00$ & $<0.040$ & $<0.030$ & $\begin{array}{c}3.00 \sim \\
5.00\end{array}$ & $\begin{array}{c}15.00 \sim \\
17.50\end{array}$ & $\begin{array}{c}3.00 \sim \\
5.00\end{array}$ & $\begin{array}{c}0.15 \sim \\
0.45\end{array}$ & $>40$ & $>(392)^{\star}$ \\
\hline
\end{tabular}

※ : Conversion value from $H R C$. 


\section{$4 \cdot 2$ ビッカース硬さ測定}

ビッカース硬さは, $\mathrm{T}$ 型ジョイントと熱間圧延板から切 り出した $7 \mathrm{~mm} \times 7 \mathrm{~mm}$, 厚さ $1 \mathrm{~mm}$ 試料の表面をエメリー 紙（\#1500）で仕上げ，押し込み荷重 $9.8 \mathrm{~N}$ ，保持時間 $30 \mathrm{~s}$ の条件で 20 点測定した. Table 2 に測定したビッカース硬 さの平均值を示す. Table 2 には，JIS-SUS630 をH900の 条件で熱処理した時の硬さの規格範囲も示す。規格範囲 はロックウェル（C スケール）HRC で与えられていたの で，ビッカース硬さ $H V$ に換算して示した. $\mathrm{T}$ 型ジョイン トのビッカース硬さは H900 熱処理した JIS-SUS630 のビ ッカース硬さの規格範囲内であった。 そこで, 熱間圧延板 に $\mathrm{H} 900$ 条件を満たす溶体化処理 $\left(1040^{\circ} \mathrm{C}, 30\right.$ 分, 水冷) と時効処理 $\left(490^{\circ} \mathrm{C}, 6\right.$ 時間, 空冷) を施した. Table 2 に 示すように，熱間圧延板のビッカース硬さは $\mathrm{T}$ 型ジョイ ントのビッカース硬さと同等であった．この結果から， T 型ジョイントには H900 に相当する熱処理が施されてい たことが判明した。

\section{$4 \cdot 3$ EBSDによる結晶方位解析}

組織は電子線後方散乱回折 (EBSD: Electron Back Scatter Diffraction）で調べた. EBSD 解析用試料（7 mm×7 mm, 厚さ $1 \mathrm{~mm}$ ) の表面は，エメリー紙（\#1500）およびダイヤ モンドペースト（粒径 $1.25 \mu \mathrm{m}$ ） で研磨仕上げしたのち, コロイダルシリカ溶液（粒径 $0.04 \mu \mathrm{m} ）$ を用いて最終仕上 げした．Fig. 3 の EBSD 像は， T 型ジョイントと熱間圧延 板の組織がマルテンサイトであることを示している。ま た， $\mathrm{T}$ 型ジョイントと熱間圧延板の両方において， A 面と B 面の EBSD 像は同じであることから，材料は異方性を 示さず，等方的であることがわかる．しかし，熱間圧延板

（Fig. 3 (b)）に比べ， T型ジョイント（Fig. 3 (a)）のマ ルテンサイトは少し粗い。この原因は，幅 $78.9 \mathrm{~mm}$ ，高さ $57.0 \mathrm{~mm}$ ，厚さ $37.7 \mathrm{~mm}$ の $\mathrm{T}$ 型ジョイント（Fig. 1 (b)）が 厚さ $20 \mathrm{~mm}$ より厚い板から作製されたため， $\mathrm{T}$ 型ジョイ ントの圧延比が小さかったことによると考えられる.

以上の化学成分分析, ビッカース硬さ測定, EBSD によ る組織観察の結果から，T型ジョイントは H900 相当の熱 処理を施された 17-4PH で作製され，その材質は健全であ ったと判断できる.

\section{$5 \cdot 1$ 破面観察}

\section{T型ジョイントの破面調査}

Fig. 4 に 型ジョイントに形成されていた半だ円形状の き裂および水平穴, 垂直穴, テーパーの各部分をマクロ写 真に示す．また，マクロ写真に示した位置（A〜F）を走 查型電子顕微鏡（SEM : Scanning Electron Microscope）で 観察した。これらの位置で得られた SEM 像を Fig. 5 に示 す. A は半だ円き裂の外側であり, 液体窒素温度で強制破 壊すなわちぜい性破壊させた位置である. そのため, SEM 像はリバーパターンを有する平坦なファセットから成る へき開破面を示した（Fig.5（a)）。半だ円き裂の境界 B で は，二次割れが形成されていた（Fig. 5（b)）。半だ円き裂 の内側 C における破面は無特徴であった（Fig. 5 (c)). 寸 なわち，ファセットのような平坦な面上にリバーパター

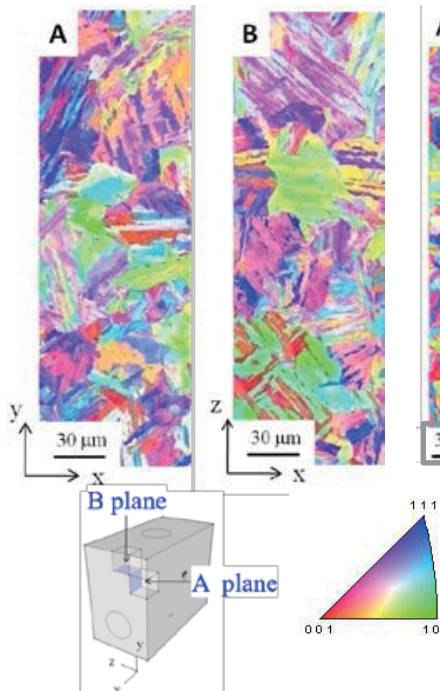

(a) T-joint

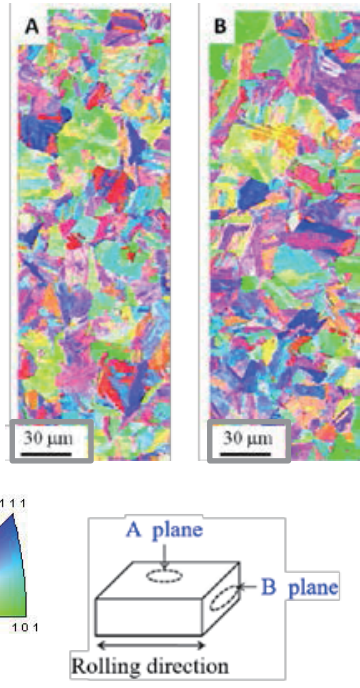

(b) Hot-rolled plate
Fig. 3 EBSD images of microstructure.

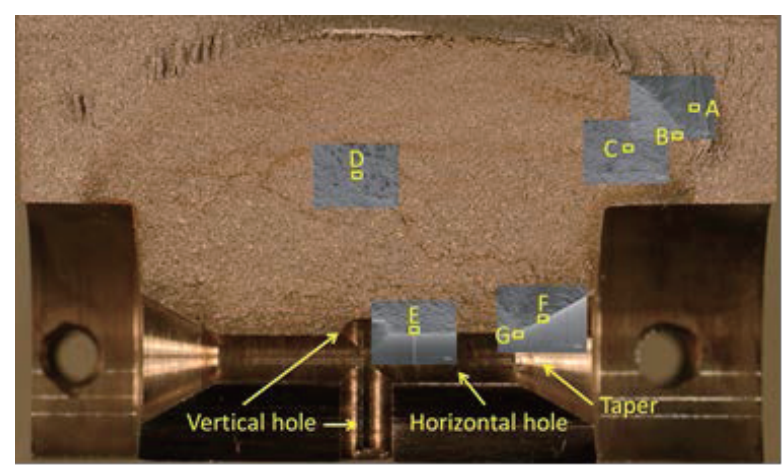

Fig. 4 Macroscopic fracture surface of T-joint.

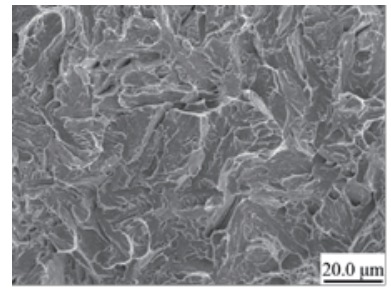

(a) Magnification of A in Fig. 4

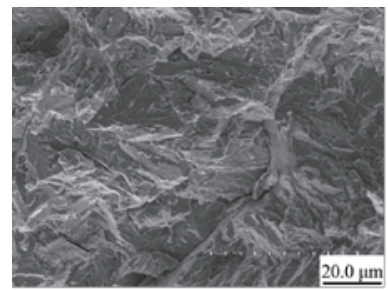

(c) Magnification of $\mathrm{C}$ in Fig. 4

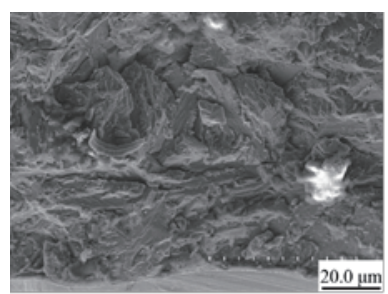

(e) Magnification of E in Fig. 4

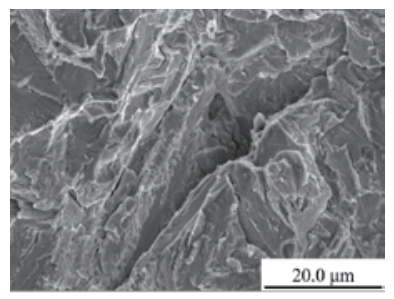

(b) Magnification of B in Fig. 4

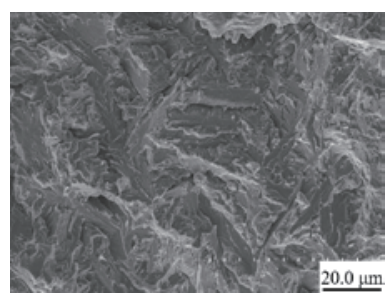

(d) Magnification of D in Fig. 4

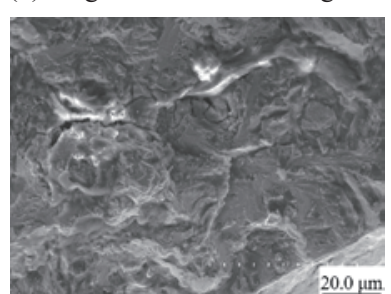

(f) Magnification of F in Fig. 4 Fig. 5 SEM images of $A$ through $F$ in Fig. 4. 
ンがほとんど観察されなかった。このような破面は擬へ き開（QC : Quasi-Cleavage）破面または水素誘起継続す心゙ り（HIS ${ }^{2}$ : Hydrogen Induced Successive Slip）破面と名付け られ，低合金鋼 SCM435，炭素鋼 SM490B，ステンレス鋼 SUS304 を用いた $115 \mathrm{MPa}$ 水素ガス中の低ひずみ速度引張

（SSRT : Slow Strain Rate Tensile）試験で報告されている 10). 同様な $\mathrm{QC}$ 破面は半だ円き裂の中央 $\mathrm{D}$, 水平穴付近 $\mathrm{E}$, テーパー付近 F においても観察された (Fig. 5 (d)〜 (f)).

破面観察に加え, 水平穴表面, 垂直穴表面, テーパー表 面を SEM で観察した. Fig. 6 中の矢印で示すように，テ 一パー表面にはく離状の欠陥が観察された．同様なはく 離状欠陥は反対側のテーパー表面でも観察された。はく 離状欠陥は，コーンアンドスレッド継手で $\mathrm{T}$ 型ジョイン トのテーパーにパイプ先端のコーンをスレッド（ねじ）で 締結されたときに形成されたと考えられる. Fig. 6 の位置 $\mathrm{H}$ の最も大きいはく離状欠陥を対象にし，角度が $10^{\circ}$ 異 なるステレオ SEM 像を取得し, 3 次元解析を行った. Fig. 7 (a) の A-A'と B-B'の断面プロファイルを Fig. 7 (b) と （c）に示す. Fig. 7 (c) から約 $13.5 \mu \mathrm{m}$ の高さの段付きが 形成されていたことがわかる，そこで，このような段付き の根元からき裂が発生・進展したと考え, 破面とテーパー 表面の両方を含めて破壊起点であろう箇所を観察したと ころ, Fig. 8（a）の SEM 像を得た（Fig.6の位置 J).この SEM 像に対しても 3 次元解析を行い, C-C'の断面プロフ アイルを Fig. 8 （b）に示した. 断面プロファイルは, はく 離状欠陥の高さ $24 \mu \mathrm{m}$ の段付きの根元からき裂が発生・ 進展したことを暗示している. Fig.8（b）には，仮想のは く離表面（破壊前）を青色の破線で示している.

Table 1 の T型ジョイントの使用履歴で説明したよう に，150 MPa 水素ガスによる 3 回目の試運転と気密試験 において水素が漏洩した. 水素ガス圧力 $150 \mathrm{MPa}$ は設計 破壊圧力 $1050 \mathrm{MPa}$ の $14 \%$ あ゙あ. この点と上述の破面 観察結果を考え合わせると, 設計破壊圧力の $14 \%$ でしか ない低負荷であるにもかかわらず，水素ガスに曝される ことで, 水素誘起き裂がはく離状欠陥から発生・進展した ため, $\mathrm{T}$ 型ジョイントの水素漏洩が起こったと推定できる.

\section{$5 \cdot 2$ NASA水素ぜい化データ}

NASA データベース ${ }^{11)}$ に示されている各種材料の水素 ぜい化データによると， T 型ジョイントに使用された 17$4 \mathrm{PH}(16 \mathrm{Cr}-4 \mathrm{Ni}-4 \mathrm{Cu}-0.03 \mathrm{Nb}, \mathrm{H} 900$ 熱処理で $\sigma \mathrm{B}>1310 \mathrm{MPa})$

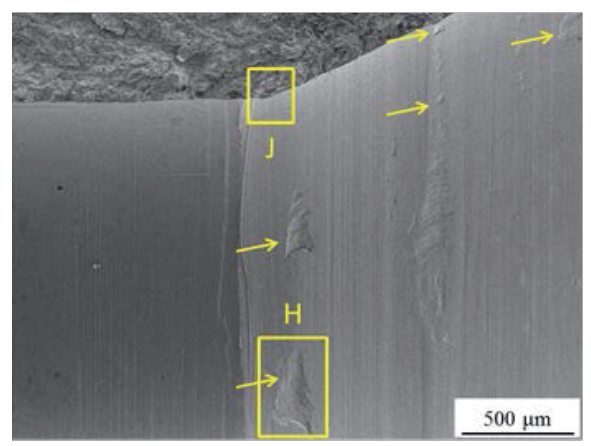

Fig. 6 SEM image of G in Fig. 4. Yellow arrows show peel-like defects.
と同族の $17-7 \mathrm{PH} \quad\left(17 \mathrm{Cr}-7 \mathrm{Ni}-1 \mathrm{Nb}, \mathrm{HT} 1050\right.$ 熱処理で $\sigma_{\mathrm{B}}>$ $1140 \mathrm{MPa}$ ）は最も水素ぜい化するグループ“Extremely embrittled”に分類されている. Table 3 は, NASAデータベ 一スと関連論文 ${ }^{12)}$ から引用した 17-7PH の引張特性であ る. 引張試験は $69 \mathrm{MPa}$ メウムガス中と $69 \mathrm{MPa}$ 水素ガ ス中で平滑丸棒試験片と切欠き丸棒試験片を用いて行わ れている. 切欠き丸棒試験片には応力集中係数 $K_{\mathrm{t}}=8.7$ の 極めて鋭い環状切欠きが加工されている. 平滑丸棒試験 片（Table 3 (a)）では，引張強度 $\sigma_{\mathrm{B}}$ はへリウムガス中と 水素ガス中ではほぼ同じであるが, 絞り $\varphi$ は水素ガス中 で著しく低下している. そのため, 水素ぜい化指標として 用いられる相対引張強度 RTS（Relative Tensile Strength）は 0.92 となり，ほぼ 1 であるが，相対絞り RRA（Relative Reduction of Area） は 0.06 となり, 極めて小さい. 切欠き 丸棒試験片（Table 3（b)）では， $\sigma_{\mathrm{B}}$ が水素ガス中で低下寸

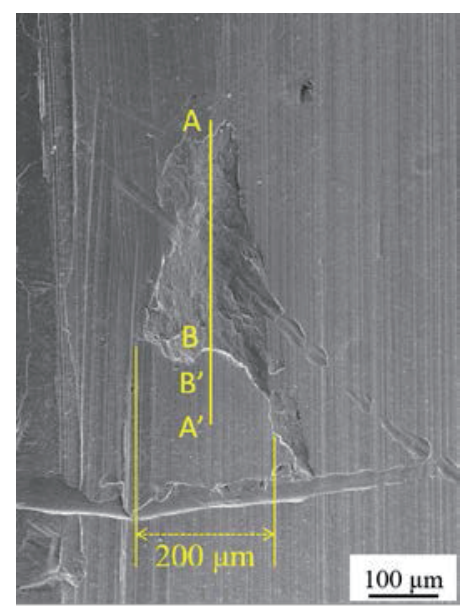

(a) SEM image

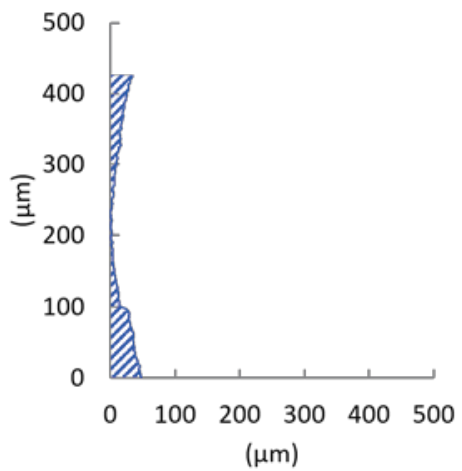

(b) Profile of A-A'

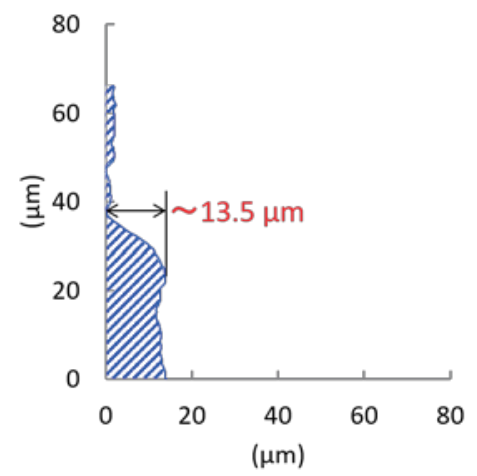

(c) Profile of B-B'

Fig. 7 Magnification of $\mathrm{H}$ in Fig. 6. 


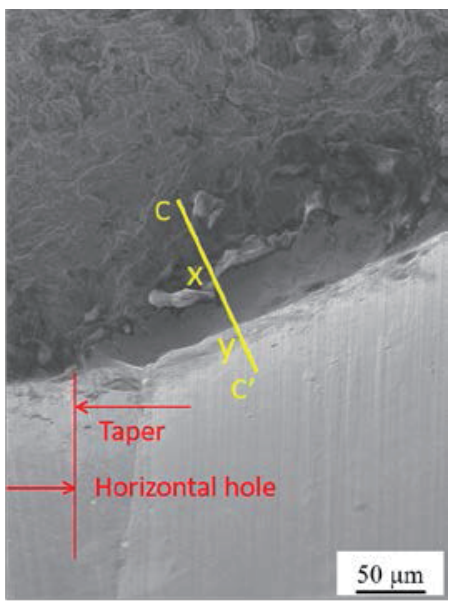

(a) SEM image

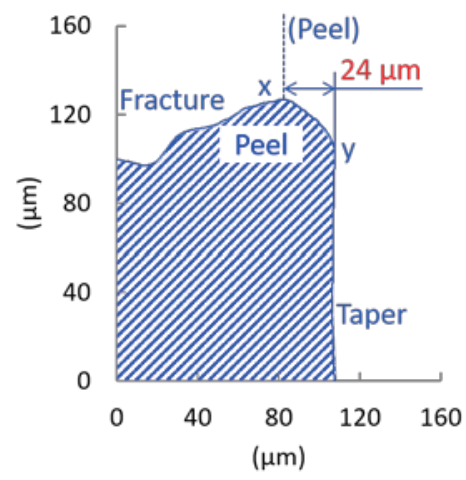

(b) Profile of C-C'

Fig. 8 Magnification of J in Fig. 6.

るため, 相対切欠き引張強度 RNTS（Relative Notch Tensile Strength）は 0.23 と小さくなり, 相対切欠き絞り RNRA (Relative Notch Reduction of Area）については有効なデー タが得られていない. NASA データベースでは，RRA と RNTS を用いて材料のグループ分けを行っている.17-7PH は, RRA (=0.06) と RNTS (=0.23) が小さいため, “Extremely embrittled”グループに分類されている．水素ぜい化をほと んど起こさない材料すなわち“Negligibly embrittled”グルー プに分類されている材料（SUS316 やA286）では, RRA 1， RNTS $\doteqdot 1$ である.
Table 3 の 17-7PH の結果が 17-4PH にも適用できると考 えると，17-4PH 製 $\mathrm{T}$ 型ジョイントの水素漏洩は次のよう に推定できる. $\mathrm{T}$ 型ジョイントの設計破壊圧力 $1050 \mathrm{MPa}$ の $14 \%$ でしない $150 \mathrm{MPa}$ 水素ガス中においては， $\mathrm{T}$ 型 ジョイントの水平穴, 垂直穴, テーパーの表面における円 周方向応力（はく離状欠陥の段差に垂直に作用する応力） は $\sigma_{0.2}$ 以下の弾性応力であると考えられる.このことを考 慮に入れると, Table 3 (a) で平滑試験片の引張強度は水 素ガス中でほとんど低下しない（RTS = 0.92）ことから, 水平穴, 垂直穴, テーパーの平滑表面では, 水素誘起き裂 は形成されないと推定できる. 一方, Table 3（b）で引張 強度が水素ガス中で切欠きにより大幅に低下する（RNTS =0.23）ことから, Fig. 6 と 7 で示したようなはく離状欠 陥部においては， $\sigma_{0.2}$ 以下の弾性応力であっても水素誘起 き裂が発生し得ると考えられる.つまり, T型ジョイント の水素漏洩ははく離状欠陥の段付き根元から発生・進展 した水素誘起き裂によると推定できる. しかし, この推定 を確実にするためには， T 型ジョイントの材料である 174PH の高圧水素ガス中における引張特性と破壊じん性(水 素誘起き裂進展下限界值) を取得し, 破壊力学解析を行う 必要がある.これについては, 第 2 報「高圧水素施設で水 素漏洩を起こした高圧配管用 $\mathrm{T}$ 型ジョイントの破壊力学 解析」で報告する.

\section{6 結 論}

高圧水素実験施設（常用圧力：99 MPa）の立ち上げにお いて, $150 \mathrm{MPa}$ 水素ガスによる試運転・気密試験を行って いたときに，17-4PH 製高圧配管用 $\mathrm{T}$ 型ジョイント（設計 破壊圧力 $1050 \mathrm{MPa}$ ）から水素ガスが漏洩した. 水素漏洩 を起こした $\mathrm{T}$ 型ジョイントの破損解析の第 1 報として, $\mathrm{T}$ 型ジョイントの材質調查と破面調查を行った. 比較材料 として，17-4PH と同等である JIS-SUS630 の熱間圧延板 （厚さ $20 \mathrm{~mm}$ ) を準備し, 材質調查で使用した. 得られた 結果を下記に示す.

（1） $\mathrm{T}$ 型ジョイントの使用履歴によると，水による耐 圧試験を $247.5 \mathrm{MPa}$ で 1 回行い, 窒素ガスによる気密試 験を $165 \mathrm{MPa}$ で 1 回, $150 \mathrm{MPa}$ で 2 回行った. これらの 2 種類の試験で問題が生じなかったので, $\mathrm{T}$ 型ジョイントは

Table 3 Tensile properties of 17-7PH in 69 MPa helium gas and hydrogen gas ${ }^{11), 12)}$.

(a) Smooth specimen

\begin{tabular}{|c|c|c|c|c|c|c|}
\hline & $\sigma_{0.2}(\mathrm{MPa})^{+}$ & $\sigma_{\mathrm{B}}(\mathrm{MPa})^{+}$ & $\delta(\%)^{+}$ & $\varphi(\%)^{+}$ & $\mathrm{RTS}^{++}$ & $\mathrm{RRA}^{++}$ \\
\hline Helium gas & 1034 & 1131 & 17 & 45 & \multirow{2}{*}{0.92} & \multirow{2}{*}{0.06} \\
\cline { 1 - 5 } Hydrogen gas & - & 1041 & 17 & 2.5 & & \\
\hline
\end{tabular}

$+\sigma_{0.2}: 0.2 \%$ proof strength, $\sigma_{\mathrm{B}}:$ Tensile strength, $\delta$ :Elongation, $\varphi:$ Reduction of area

$++\mathrm{RTS}\left(=\sigma_{\mathrm{B}, \mathrm{H}} / \sigma_{\mathrm{B}, \mathrm{He}}\right):$ Relative Tensile Strength, RRA $\left(=\varphi_{\mathrm{H}} / \varphi_{\mathrm{He}}\right)$ : Relative Reduction of Area

(b) Notched specimen $\left(K_{\mathrm{t}}=8.7\right)$

\begin{tabular}{|c|c|c|c|c|c|c|}
\hline & $\sigma_{0.2}(\mathrm{MPa})^{*}$ & $\sigma_{\mathrm{B}}(\mathrm{MPa})^{*}$ & $\delta(\%)^{*}$ & $\varphi(\%)^{*}$ & RNTS $^{* *}$ & RNRA $^{* *}$ \\
\hline Helium gas & - & 2082 & - & 0.6 & \multirow{2}{*}{0.23} & - \\
\cline { 1 - 5 } Hydrogen gas & - & 483 & - & 0.4 & & \\
\hline
\end{tabular}

$* \sigma_{0.2}: 0.2 \%$ proof strength, $\sigma_{\mathrm{B}}:$ Tensile strength, $\delta$ :Elongation, $\varphi:$ Reduction of area

$* *$ RNTS $\left(=\sigma_{\mathrm{B}, \mathrm{H}} / \sigma_{\mathrm{B}, \mathrm{He}}\right)$ : Relative Notched Tensile Strength, RNRA $\left(=\varphi_{\mathrm{H}} / \varphi_{\mathrm{He}}\right)$ : Relative Notched Reduction of Area 
適正に作製されていたと判断できた. 2 種類の試験に続き, $150 \mathrm{MPa}$ 水素ガスによる試運転・気密試験を 3 回行った ところ, 3 回目の試運転・気密試験で水素漏洩が起こった.

（2） T 型ジョイントと SUS630 の熱間圧延板の化学成 分分析, ビッカース硬さ測定, EBSD による組織観察から, $\mathrm{T}$ 型ジョイントは H900 の熱処理が施された 17-4PH で作 製され，その材質は健全であったことが明らかになった。

（3） $\mathrm{T}$ 型ジョイントの破面観察によると，形成されて いた半だ円き裂は擬へき開破面で覆われていた。テーパ 一表面には, はく離状欠陥が存在した。 これらの結果から, 設計破壊圧力 $1050 \mathrm{MPa}$ の $14 \%$ である比較的低圧の 150 $\mathrm{MPa}$ 水素ガス中においても，水素誘起き裂がはく離状欠 陷から発生・進展することによって, $\mathrm{T}$ 型ジョイントの水 素漏洩が起こったと推定できた。しかし，この推定を確実 にするためには，17-4PH と同等である SUS630 を用い， 高圧水素ガス中における引張特性と破壊じん性（水素誘 起き裂進展下限界值) を取得し, 破壊力学解析を行う必要 がある。

\section{参 考 文 献}

1) H. Onaka, "Development status of fuel cell vehicle", Journal of High Temperature Society, Vol.35, No.5, pp.231-238 (2009).

2) Y. Murakami, T. Kanezaki, Y. Fukushima, H. Tanaka, J. Tomuro, K. Kuboyama, M. Matsue, M. Ito and H. Ando, "Failure analysis of SUS316L flexible hose for hydrogen station and fatigue life prediction method", Transactions of the Japan Society of Mechanical Engineers, Series A, Vol.75, No.749, pp.93-102 (2009).

3) T. Miyamoto, T. Kanezaki, H. Tasaki, N. Kobayashi, S. Matsuoka and Y. Murakami, "Failure analysis on the diaphragm of a high pressure hydrogen transducer", Journal of the Society of Materials Science, Japan, Vol.59, No.12, pp.916-923 (2010).

4) T. Matsuo, J. Yamabe, Y. Fukushima, S. Matsuoka and Y. Murakami, "Effect of microstructure on charpy impact properties and LBB assessment of SCM435 steel for storage cylinders of $35 \mathrm{MPa}$ hydrogen stations", Journal of the Society of Materials Science, Japan, Vol.59, No.12, pp.924-931 (2010).

5) A. Macadre, M. Artamonov, S. Matsuoka and J. Furtado, "Effects of hydrogen pressure and test frequency on fatigue crack growth properties of $\mathrm{Ni}-\mathrm{Cr}-\mathrm{Mo}$ steel candidate for a storage cylinder of a $70 \mathrm{MPa}$ hydrogen filling station", Engineering Fracture Mechanics, Vol.78, No.18, pp.3196-3211 (2011).

6) H. Itoga, S. Watanabe, Y. Fukushima, S. Matsuoka and Y. Murakami, "Fatigue crack growth of aluminum alloy A6061-T6 in high pressure hydrogen gas and failure analysis on $35 \mathrm{MPa}$ compressed hydrogen tanks VH3 for fuel cell vehicles", Transactions of the Japan Society of Mechanical Engineers, Series A, Vol.78, No.788, pp.442457 (2012).

7) S. Matsuoka, S. Hamada, H. Itoga, M. Nakamura, S. Okazaki and H. Matsunaga, "Case study on cooling pipe of pre-cooler used for verification test of $70 \mathrm{MPa}$ hydrogen station", Transactions of the JSME, Vol.83, No.848, DOI:10.1299/transjsme.16-00459 (2017).

8) JIS G 4303, Stainless steel bars (2012).

9) JIS G 4304, Hot-rolled stainless steel plate, sheet and strip (2012).

10) O. Takakuwa, J. Yamabe, H. Matsunaga, Y. Furuya and S. Matsuoka, "Comprehensive understanding of ductility loss mechanisms in various steels with external and internal hydrogen", Metallurgical and Materials Transactions A, Vol.48, Issue.11, pp.5717-5732 (2017).

11) NASA, NSS 1740.16 , Safety standard for hydrogen and hydrogen systems, Washington, D.C (1997).

12) W. T. Chandler and R. J. Walter, "Effect of HighPressure Hydrogen on Metals", The 1968 Materials Engineering Exposition \& Congress, American Society for Metals (1968). 